\title{
Frequency of intraendothelial 'virus-like' particles: An electron microscopy study of 376 human renal biopsies
}

\author{
J. BARIETY, D. RICHER, M. D. APPAY, J. GROSSETETE, AND P. CALLARD
}

From the Laboratoire de Morphologie et d'Immunopathologie Rénales, CNRS ERA 48 and INSERM U 28, Hôpital Broussais, Paris, France

SYNOPSIS Intraendothelial 'virus-like' particles were found in all cases requiring a renal biopsy: in $89 \%$ of patients with systemic lupus erythematosus (SLE), in $73 \%$ of those receiving renal transplants more than one year before, and in $24.5 \%$ of all other renal biopsies.

The exact nature of the intraendothelial 'virus-like' inclusions detected in the renal biopsies of patients with SLE and their degree of specificity remain highly controversial. In the present paper we hope to provide further insight into the relationship between the prevalence and the occurrence of such particles and the various conditions for which the renal biopsies were performed.

\section{Material}

Three hundred and seventy-six renal biopsies were studied by light and electron microscopy and 243 out of these were also studied by immunohistochemistry.

The 376 renal biopsies performed on 356 patients showed a broad spectrum of disease (see Table). Three hundred and twenty patients showed no evidence of SLE, and 36 had SLE proved by positive LE cell preparations, a raised titre of circulating antinuclear antibodies, or both. The patients with SLE showed three or more of the following signs and symptoms: polyarthritis, characteristic skin lesions, thrombocytopenia, leucopenia, Coombs test-positive anaemia. The diagnoses in the 320 patients without evidence of SLE were histological, except in those cases where the clinical diagnoses appeared more explicit. None of the patients had any history of exposure to drugs known to produce a systemic lupus erythematosus-like syndrome.

\section{Methods}

The techniques of light microscopy, of immuno-

Received for publication 18 September 1972. histochemistry, and of electron microscopy have already been described (Bariéty, Druet, Lagrue, Samarcq, and Milliez, 1970a). Two or three glomeruli from each renal biopsy were examined by

\begin{tabular}{|c|c|c|c|}
\hline Diagnosis & $\begin{array}{l}\text { No. of } \\
\text { Patients }\end{array}$ & $\begin{array}{l}\text { No. of } \\
\text { Biopsies }\end{array}$ & $\begin{array}{l}\text { Biopsies } \\
\text { with } \\
\text { Inclusions }\end{array}$ \\
\hline $\begin{array}{l}\text { Systemic lupus erythematosus } \\
\text { Transplants more than one }\end{array}$ & 36 & 36 & 32 \\
\hline year after transplantation & 22 & 37 & $22^{4}$ \\
\hline Immediate renal graft biopsies & 40 & 40 & 6 \\
\hline Scleroderma & 3 & 3 & 2 \\
\hline $\begin{array}{l}\text { Discoid lupus } \\
\text { Rheumatoid arthritis without }\end{array}$ & 1 & 1 & 1 \\
\hline nephropathy & 6 & 6 & 2 \\
\hline Minimal glomerular changes & 42 & 42 & 10 \\
\hline $\begin{array}{l}\text { Membranous nephropathy } \\
\text { Membranoproliferative }\end{array}$ & 25 & 27 & $8^{1}$ \\
\hline $\begin{array}{l}\text { glomerulonephritis } \\
\text { Glomerulonephritis with IgA }\end{array}$ & 47 & 48 & $16^{2}$ \\
\hline mesangial deposits & 25 & 25 & 7 \\
\hline $\begin{array}{l}\text { Acute glomerulonephritis } \\
\text { Glomerulonephritis with extra- }\end{array}$ & 12 & 14 & $2^{3}$ \\
\hline capillary proliferation & 4 & 4 & 1 \\
\hline Focal hyalinosis & 11 & 11 & 2 \\
\hline Diabetic nephropathy & 13 & 13 & 4 \\
\hline Amyloidosis & 7 & 7 & 2 \\
\hline Toxaemia of pregnancy & 5 & 5 & 1 \\
\hline Periodic disease & 1 & 1 & 0 \\
\hline Fabry's disease & 1 & 1 & $\mathbf{0}$ \\
\hline Alport's syndrome & 1 & 1 & 1 \\
\hline Primary arterial hypertension & 9 & 9 & 2 \\
\hline Chronic pyelonephritis & 7 & 7 & 1 \\
\hline Miscellaneous & 20 & 20 & 4 \\
\hline Unclassified renal lesions & 18 & 18 & 4 \\
\hline
\end{tabular}

Table Frequency of intraendothelial 'virus-like' particles

${ }^{1}$ Two patients had two biopsies in which inclusions were detected. 'One patient had two biopsies in which inclusions were detected.

'Two patients had two biopsies in which no inclusion was detected.

-Twelve patients had successive biopsies. Inclusions were detected in two biopsies from two patients and in three biopsies from two patients. No inclusions were detected in two biopsies from three patients and in three biopsies from one patient. Four patients underwent two biopsies: one biopsy showed inclusions, the other no inclusions. 
electron microscopy. Each glomerulus and each interstitial capillary or arteriole was scanned for cytoplasmic inclusions at magnifications ranging from 9000 to 12000 . At least three grids were examined before a biopsy was declared to be negative.

A statistical study was performed on patients in whom one or several renal biopsies showed inclusions. The $\chi^{2}$ test of Pearson was used whenever the number of cases was sufficient, the corrected $\chi^{2}$ test of Yates in the small groups.

\section{Results}

The virus-like inclusions were observed in the endothelial cells of glomerular capillaries (Fig. 1), of interstitial capillaries, of arterioles, but in no other cell of the renal cortex. They were clustered, interwoven microtubules. When cross-sectioned, they were circular and the outer diameter was about $220 \AA$. The centre was often less electron-dense than the periphery. Circular outlines superimposed upon a longitudinal profile suggested branching. The clusters varied in size and were bound in a single membrane, the continuity of which was more or less

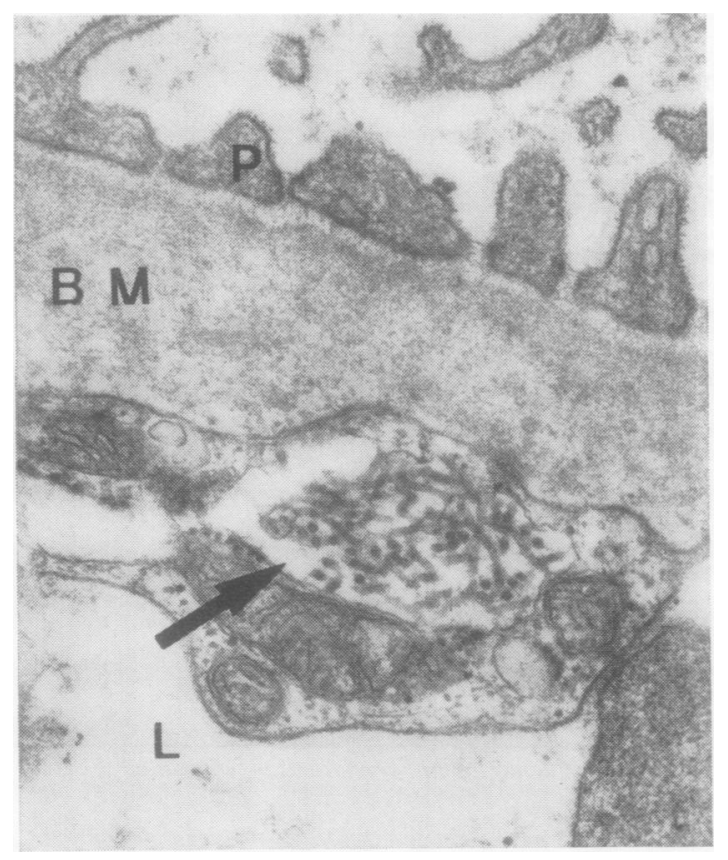

Fig. Electron micrograph illustrating the typical 'virus-like' inclusions (arrow) lying within the dilated endoplasmic reticulum of a glomerular endothelial cell (E) from an immediate renal graft biopsy. P: pedicle; BM: basement membrane; L: lumen ( $\times 34000)$. apparent. This membrane was often continuous with the endoplasmic reticulum, but was generally free of ribosomes. Microtubules were located either near the nucleus, sometimes even lying in the perinuclear space, or far from the nucleus. No specific relationship between these microtubules and other concomitant cytoplasmic organelles was established. Their number varied considerably from के one case to another. The clustered, interwoven $\overrightarrow{0}$ microtubules showed the same characteristics in patients with SLE and without SLE. However, in $\vec{\omega}$ the patients with SLE and in the patients with renal transplants more than one year after transplantation, they were generally more numerous and hence much easier to detect.

A much higher prevalence of inclusions was observed in patients with SLE $(89 \%)$ than in 은 patients without any evidence of SLE $(28 \%)$ $(P<0.001)$. Eight patients with SLE showed no sign of nephropathy and their renal biopsies were normal by light microscopy and by immunohistochemistry. Inclusions were seen in these eight biopsies. Twenty-eight patients with SLE had definite clinical or histopathological evidence of nephropathy. Inclusions were detected in biopsies of 24 of them.

Considering the patients without evidence of SLE, in five groups there were sufficient numbers of matched cases: (1) idiopathic proteinuria or nephrotic syndrome with minimal glomerular changes; (2) membranous nephropathy; (3) membranoproliferative glomerulonephritis; (4) glomerulonephritis with IgA mesangial deposits; and (5) immediate renal graft biopsies. No statistically significant difference could be established between the five groups, as far as the occurrence of inclusions was concerned. No significant difference could be established either between the five groups as a whole and the groups of acute glomerulonephritis, and of diabetic nephropathies which included fewer cases (corrected $\chi^{2}$ test of Yates) but in kidney transplants more than one year after transplantation the presence of inclusions was statistically more frequent than in the five groups $(P<0.001)$ and less frequent than in patients with SLE. However, the difference with SLE was not significant. We have the renal biopsies taken immediately after grafting of 12 of the 16 patients in whom a renal biopsy performed more than one year after transplantation has shown inclusions. Inclusions had already been observed in the renal biopsies immediately after grafting in three cases. No correlation was noticed between the occurrence and prevalence of the inclusions and the clinical, biological, histopathological, and immunohistochemical signs or possible prior therapy by steroids or immunosuppressive drugs. 


\section{Discussion}

We will confine the discussion to two points: (1) the degree of specificity for SLE of the inclusions and (2) their nature.

DEGREE OF SPECIFICITY OF THE

INCLUSIONS

All authors insist upon the high prevalence or even the constancy of the inclusions in the renal biopsies of patients with SLE (Györkey, 1969; Norton, 1969; Kawano, Miller, and Kimmelstiel, 1969; Bariéty and Milliez, 1970b; Haas and Yunis, 1970; Grausz, Earley, Stephens, Lee, and Hopper, 1970; Bloodworth and Shelp, 1970; Hurd, Eigenbrodt, Worthen, Strunk, and Ziff, 1971; Garancis, Komorowski, Bernhard, and Straumfjord, 1971; Tisher, Kelso, Robinson, Gunnells, and Burkholder, 1971). In the patients with SLE, identical structures were also described in the endothelial cytoplasm of muscular (Norton, 1969; Feorino, Hierholzer, and Norton, 1970), dermal (Norton, 1969; Haas and Yunis, 1970; Feorino et al, 1970; Prunieras, Grupper, Durepaire, Beltzer-Garelly, and Régnier, 1970), and synovial capillaries (Schumacher, 1970) in the lymph node tissue (Haas and Yunis, 1970) and in the cytoplasm of mononuclear cells of peripheral blood (Bariéty, Amor, Kahan, Balafrej, and Delbarre, 1971; Györkey and Sinkovics, 1971).

The results obtained in the renal biopsies of patients without any evidence of SLE are highly divergent. According to some authors the inclusions are observed in less than $5 \%$ of cases (Györkey, 1969; Kawano et al, 1969; Grausz et al, 1970; Tisher et al, 1971; Györkey, Sinkovics, Min, and Györkey, 1972), and to others in 20 to $25 \%$ of the cases (Hurd et al, 1971; Garancis et al, 1971).

Our results show that the inclusions (as they are defined by ultrastructure) are not specific for SLE but they may be found, as a rule, in all cases requiring a renal biopsy. This is in agreement with the numerous workers who showed inclusions morphologically identical to those of SLE in various diseases without any apparent relationship to SLE (Chandra, 1968; Moses, Glade, Kasel, Rosenthal, Hirshaut, and Chessin, 1968; Norton, 1969; Recher, Sinkovics, Sykes, and Whitescarver, 1969; Haas and Yunis, 1970; Feorino et al, 1970; Grausz et al, 1970; Pincus, Blacklow, Grimley, and Bellanti, 1970; Hurd et al, 1971; Garancis et al, 1971; Uzman, Saito, and Kasac, 1971 ; Eknoyan, Györkey, Dichoso, Martinez-Maldonado, Suki, and Györkey, 1972). To our knowledge the evidence of the absence of detectable inclusions against the diagnosis of SLE is much stronger than the evidence of their presence in favour of the diagnosis. However, the rate of prevalence of the inclusions in the renal biop- sies led us to reclassify our patients into three groups: (1) the group of patients with SLE in which the prevalence rate is very high (89\% of the cases); (2) the group with renal transplants more than one year after transplantation in which the rate is high $(73 \%$ of the cases); and (3) the group of the other patients in whom the average rate of prevalence is $24.5 \%$ and ranges from 15 to $30 \%$ when the percentage can be calculated. In the third group especially, the percentage of positive cases is certainly too low; some scattered inclusions may be located on the outside of the planes of sections examined. In the third group we included the immediate renal graft biopsies in $15 \%$ of which inclusions were detected. If it was confirmed that the inclusions are not found in the renal biopsies of normal volunteers (Hurd et al, 1971) while they are found in the immediate renal graft biopsies, that would mean that the inclusions are not viral and that they are related to changes such as ischaemia occurring in the course of transplantation. The endothelial inclusions may possibly be observed in normal subjects too, but the number of volunteers who underwent biopsies may be insufficient for objective interpretation.

NATURE OF THE INCLUSIONS

The nature of the inclusions remains unknown. The hypothesis of viral origin is based only upon a morphological analogy with myxo- and paramyxo-RNA virus (Györkey, Min, Sincovics, and Györkey, 1969; Norton, 1969; Kawano et al, 1969; Grausz et al, 1970; Bloodworth and Shelp, 1970; Hurd et al, 1971). Moreover those structures yielded to digestion by RNase but not by DNase (Györkey and Sinkovics, 1971). Unfortunately until now it has not been possible to characterize the virus implicated in the process or even to ascertain that it actually was a virus and that despite a series of studies with a variety of morphological, immunological, and tissue culture techniques (Norton, 1969; Feorino et al, 1970; Pincus et al, 1970). High titres of circulating antibodies against paramyxoviruses, non-myxoviruses RNA viruses, and DNA viruses (Pincus et al, 1970; Phillips and Christian, 1970; Hollinger, Sharp, Lidsky, and Rawls, 1971) may simply represent a non-specific hyperimmune response known in SLE.

If the inclusions observed in SLE are virus, five hypotheses may be postulated: (1) a common virus without any bearing on SLE: this hypothesis is unlikely because it does not account for the high prevalence and frequency of inclusions in patients with SLE. (2) A common virus, the proliferation of which is a consequence of drug therapy: this is hardly credible for the inclusions were identified in patients treated by steroid therapy or immunosuppressive agents as well as in untreated patients. 
(3) A common virus that the patients with SLE are unable to eliminate. (4) A specific virus responsible for the disease: this is doubtful, for it is untenable that $28 \%$ of our patients without any evidence of SLE in whom inclusions were found should be potential victims of SLE. However, nothing proves that the nature of the inclusions observed in the patients with SLE is the same as that of inclusions in patients without SLE even if they show the same ultrastructural characteristics. Nothing proves, either, that some subjects without any evidence of lupus when the inclusions were detected will not show later clear clinical and biological signs of SLE. (5) A common virus which, under particular circumstances, induces or aggravates SLE. If we accept this hypothesis, this virus would be analogous to Gross virus which is very frequently found in several strains of mice and is constant in NZB, NZB/W mice in which the spontaneous disease is very similar to human SLE. This virus could act either as an immuninogen (Talal, Steinberg, Jacobs, Chused, and Gazdar, 1971; Dixon, Oldstone, and Tonietti, 1971) or as an adjuvant, or as both (Hollinger et al, 1971), and could participate in the hyperimmune state observed in SLE.

Other hypotheses to explain the nature of inclusions have been suggested: morphological changes related to a viral infection (Garancis et al, 1971), non-specific changes in the endoplasmic reticulum resulting from cell injury (Chandra, 1968; Haas and Yunis, 1970; Pincus et al, 1970; Tisher et al, 1971), or phagocytosis by the endothelial cells of immune complexes or of cellular material released in the circulation from injured cells (Haas and Yunis, 1970; Hurd et al, 1971). However, the presence of the inclusions in the endoplasmic reticulum and the perinuclear space is in favour of a material produced by the cell rather than of phagocytosed material. The possibility that these structures, at least in lymphoid cells, may reflect the production of immunoglobulins has been also suggested (Uzman et al, 1971). So far none of these hypotheses have been confirmed.

We thank Professors Delbarre, Fritel, and Lagrue for entrusting us with the renal biopsies of several patients.

\section{References}

Bariéty, J., Amor, B., Kahan, A., Balafrej, L., and Delbarre, F. (1971). Ultrastructural anomalies in mononuclear cells of peripheral blood in SLE: presence of virus-like inclusions. Rev. Europ. Étud. clin. biol., 16, 715-720.

Bariéty, J., Druet, P., Lagrue, G., Samarcq, P., and Milliez, P. (1970a). Les glomérulopathies 'extra-membraneuses' (G.E.M.). Etude morphologique en microscopie optique, électronique et en immunofluorescence. Path. et Biol., 18, 5-32.

Bariéty, J., and Milliez, P. (1970b). Inclusions d'aspect 'viral' dans le rein des lupus érythémateux disséminés. Bull. Acad. nat. Méd. (Paris), 154, 249-252.
Bloodworth, J. M. B., Jr., and Shelp, W. D. (1970). Endothelial cytoplasmic inclusions. Arch. Path., 90, 252-258.

Chandra, S. (1968). Undulating tubules associated with endoplasmic reticulum in pathologic tissues. Lab. Invest., 18, 422-428.

Dixon, F. J., Oldstone, M. B. A., and Tonietti. G. (1971). Pathogenesis of immune complex glomerulonephritis of New Zealand mice. J. exp. Med., 134, 65S-71S.

Eknoyan, G., Györkey, F., Dichoso, C., Martinez-Maldonado, M. Suki, W. N., and Györkey, P. (1972). Renal morphological and immunological changes associated with acute viral hepatites. Kidney international, 1, 413-419.

Feorino, P. M., Hierholzer, J. C., and Norton, W. L. (1970). Viral isolation studies of inclusion positive biopsy from human connective tissue diseases. Arthr. and Rheum., 13, 378-380.

Garancis, J. C., Komorowski, R. A., Bernhard, G. C., and Straumfjord, J. V. (1971). Significance of cytoplasmic microtubules in lupus nephritis. Amer. J. Path., 64, 1-12.

Grausz, H., Earley, L. E., Stephens, B. G., Lee, J. C., and Hopper, J., Jr. (1970). Diagnostic import of virus-like particles in the glomerular endothelium of patients with systemic lupus erythematosus. New Engl. J. Med., 283, 506-511.

Györkey, F. (1969). 'Virus' particles appear in lupus. Med. Wld News, $10,18$.

Györkey, F., Min, K. W., Sincovics, J. G., and Györkey, P. (1969). Systemic lupus erythematosus and myxovirus. New Engl. $J$. Med., 280, 333.

Györkey, F., and Sinkovics, J. G. (1971). Microtubules of systemic. lupus erythematosus. (Letter). Lancet, 1, 131-132.

Györkey, F., Sinkovics, J. G., Min, K. W., and Györkey, P. (1972). A morphologic study on the occurrence and distribution of structures resembling viral nucleocapsids in collagen diseases. Amer. J. Med., 53, 148-158

Haas, J. E., and Yunis, E. J. (1970). Tubular inclusions of systemic lupus erythematosus: ultrastructural observations regarding their possible viral nature. Exp. molec. Path., 12, 257-263.

Hollinger, F. B., Sharp, J. T., Lidsky, M. D., and Rawls, W. E. (1971). Antibodies to viral antigens in systemic lupus erythematosus. Arthr. and Rheum., 14, 1-11.

Hurd, E. R., Eigenbrodt, E., Worthen, H., Strunk, S. W., and Ziff, M. (1971). Glomerular cytoplasmic tubular structures in renal biopsies of patients with systemic lupus erythematosus and other diseases. Arthr and Rheum., 14, 539-550.

Kawano, K., Miller, L., and Kimmelstiel, P. (1969). Virus-like structures in lupus erythematosus. New Engl. J. Med., 281, 12281229.

Moses, H. L., Glade, P. R., Kasel, J. A., Rosenthal, A. S., Hirshaut, Y., and Chessin, L. N. (1968). Infectious mononucleosis: detection of herpes like virus and reticular aggregates of smal cytoplasmic particles in continuous lymphoid cell lines derived from peripheral blood. Proc. nat. Acad. Sci. (Wash.), 60, 489-496.

Norton, W. L. (1969). Endothelial inclusions in active lesions of systemic lupus erythematosus. J. Lab. clin. Med., 74, 369-379.

Phillips, P. E., and Christian, C. L. (1970). Myxovirus antibody increases in human connective tissue disease. Science, 168, 982-984.

Pincus, T., Blacklow, N. R., Grimley, P. M., and Bellanti, J. A. (1970). Glomerular microtubules of systemic lupus erythematosus. Lancet, 2, 1058-1061.

Prunieras, M., Grupper, C., Durepaire, R., Beltzer-Garelly, E., and Régnier, M. (1970). Etude ultrastucturale de la peau dans 42 cas de lupus érythémateux. Presse méd., 78, 2475-2479.

Recher, L., Sinkovics, J. G., Sykes, J. A., and Whitescarver, J. (1969). Electron microscopic studies of suspension cultures derived from human leukemic and nonleukemic sources. Cancer Res., 29, 271-285.

Schumacher, H. R.,Jr. (1970). Tubular paramyxovirus-like structures in synovial vascular endothelium. Ann. rheum. Dis., 29, 445-447.

Talal, N., Steinberg, A. D., Jacobs, M. E., Chused, T. M., and Gazdar, A. F. (1971). Immune cell cooperation, viruses, and antibodies to nucleic acids in New Zealand mice. J. exp. Med., 134, 52S-64LS.

Tisher, C. C., Kelso, H. B., Robinson, R. R., Gunnells, J. C., and Burkholder, P. M. (1971). Intraendothelial inclusions in kidneys of patients with systemic lupus erythematosus. Ann. intern. Med., 75, 537-547.

Uzman, B. G., Saito, H., and Kasac, M. (1971). Tubular arrays in the endoplasmic reticulum in human tumor cells. Lab. Invest., 24, 492-498. 